\title{
How Did Religion Consolidate the Rule of Ancient Kingship: Take the Roman Empire as an Example
}

\author{
Yifan Chen ${ }^{1, \dagger}$, Yancheng Wang ${ }^{2, *, \dagger}$ \\ ${ }^{1}$ Hangzhou Foreign Languages School, Hangzhou, China \\ ${ }^{2}$ School of Public Administration, Central South University, Changsha,China \\ ${ }^{*}$ Corresponding author.Email:8101190109@csu.edu.cn \\ ${ }^{\dagger}$ These authors contributed equally.
}

\begin{abstract}
Roman Empire intrigues many people to explore it and raise its veil, so we do some pieces of research on this topic and surprisingly find that Christianity is closely related to this mysterious empire. Therefore, we decided to write about the role of religion in consolidation of ancient royal power and looked specifically into Roman Empire and Christianity, which is a typical example in relationship of religion and Empire. This essay is divided into several sections. First, in order to help readers understand the essay better, there is an introduction which provides readers a general background information of Roman Empire and Christianity. Then, we will look into the development of Christianity in Roman Empire and the ways that Christianity helped Roman Empire to rule or use its power, in other words, we closely examine how Christianity ultimately became the official religion in Roman Empire. Moreover, we discuss the role of religion in maintaining imperial power and provide examples from a variety of countries. The last but not the least, in the last part, we not only summarize our analysis into a conclusion, but also compare our essay with other essays with similar subject and suggest our advantages while providing the drawbacks of our essay. This research is meaningful, since it helps people to understand the role of religion in politics. With this essay, readers are able to learn how emperors use religions as a weapon and also reflect on themselves and current society, considering deeply on the pros and cons of religions in the development of both countries and empires.
\end{abstract}

Keywords: religion; kingship; rule; Imperium Romanum

\section{INTRODUCTION}

In the later period of Rome, civil wars were still frequent and people were living in a miserable life. At that time, the empire was divided into four parts, ruled by different emperors, and Constantine was one of these contenders. When Constantine was attacking Italy, a large meteorite fell from the sky. Everyone thought it was an ominous omen, but a Christian solder told Constantine that this was not a bad omen, but a good omen. In the end, Constantine really won the war. In that battle, the bridge miraculously broke and collapsed, causing the enemy commander to fall directly into the water and die. With this good fortune, Constantine became the Roman emperor of the west. After that, Constantine unified Rome and became the sole emperor. He convened the Council of Nicaea to help Christianity establish the official creed and unify the Christian faith. At this time, the theory of the Trinity was born. Although Constantine was a great help to Christianity, he did not position Christianity as the state religion. During his reign, Christianity and other religions had been supported by Christianity and there was no obvious bias, and he was not baptized until his death. Christian, he believed in Sun God before.

It was not until $380 \mathrm{AD}$ that another Roman emperor Theodosius designated Christianity as the state religion and immediately began to ban other religions. Christianity originated from Judaism, and Judaism was believed by Jews living in West Asia. Therefore, Christianity did not emerge in the early Roman Republic. When the large-scale expansion and conquest of the late Roman Republic finally extended its tentacles into West Asia, Judaism was able to spread across the vast territory of the empire, and more and more people from the lower classes believed in it. When Rome entered the Empire from the Republic, slavery still stayed unchanged. Therefore, the lower class people need a spiritual support 
to support their miserable lives, so Christianity was ultimately chosen.

Previous studies which have been done before have mostly focused on how the ancient Roman Empire strengthened its power over a vast territory. However, there is a lack of focused research on religion. In fact, religion and politics have a close interactive relationship. Based on the case of the ancient Roman Empire, this essay mainly focuses on positive effects that Christianity has on Roman Empire. In this research, we will first talk about origin and development of Christianity in Roman Empire, especially those of how Constantine used Christianity, which is a religion, to seize and consolidate his power in the empire. Secondly, we will discuss the ways that Christianity construct the legitimacy of royal power and further consolidate Emperor's power. The last but not least, we will propose the role of Christianity in maintaining the power of the empire.

\section{THE FORMATION AND DEVELOPMENT OF CHRISTIANITY IN ROMAN EMPIRE}

Ancient Rome was a deeply religious society and religious and political office often went hand in hand. In the early stage of the establishment of Roman empire, Rome encountered new religions, tolerating most and incorporating some into Roman life. Its religion is diverse and polytheistic, which means that the Romans worshiped a large collection of gods, some of them borrowed from the Ancient Greeks. Christianity is one of the official religion in Rome Empire, though religion was extremely diverse through its expansion.

Christianity developed in Judea in the mid-first century CE, based first on the teachings of Jesus and later on the writings and missionary work of Paul of Tarsus. At first, Christianity was a small-scaled, unorganized sect that promised personal salvation after death. Although Christianity struggled to survive in the history, it ultimately successfully survived. At the end of third century $\mathrm{AD}$, though there were not many followers, Christian church has formed its own primary but organized structure. Christianity divided the Roman Empire into five dioceses, from the archdioceses down, which branched off into a well-organized pyramidal structure. At the same time, Christianity was no longer a scatter-like religion composed of missionaries traveling everywhere, but formed a top-down centralized organization, whose social mobilization ability was no longer comparable to other religions. Constantine, who was eager to rule Rome, also urgently needed such organization which had high social mobilization capacity to serve him. Since Christians believe in Jesus, which is the same god the Jews believed in, Christianity finally gained plenty of followers from Jewish people and also non-Jewish people. In the decades after Jesus's death, the Apostle Paul wrote many letters that are now part of the
New Testament of the Christian Bible. Paul was a Roman citizen and sent these letters to small communities of Christians living throughout the Roman Empire. The letters show us that Paul and his fellow Christians were still figuring out exactly what being a Christian meant. Issues related to the exact relationship between Judaism and Christianity, and between Christianity and the Roman government, were prominent topics of discussion. In 313 $\mathrm{CE}$, the emperor Constantine issued the Edict of Milan, which granted Christianity-as well as most other religions-legal status[1]. While this was an important development in the history of Christianity, it was not a total replacement of traditional Roman beliefs with Christianity. Then in $325 \mathrm{CE}$, Constantine called the Council of Nicaea, which was a gathering of Christian leaders to determine the formal — or orthodox — beliefs of Christianity. The result of this council was the Nicene Creed, which laid out the agreed upon beliefs of the council. In $380 \mathrm{CE}$, the emperor Theodosius issued the Edict of Thessalonica, which made Christianity, specifically Nicene Christianity, the official religion of the Roman Empire. Most other Christian sects were deemed heretical, lost their legal status, and had their properties confiscated by the Roman state.

In the process of the unification war, Constantine needed to recruit a large number of soldiers. During this period, a large number of Goths who believed in Christianity and were good at fighting entered the army of the Empire and became a force that could not be ignored. Christian soldiers were especially brave in battle because of the Christian doctrine of sacrifice for the sake of religion[2]. As time went on, the Number of Christians in the army increased and even formed the main force of the Imperial Spanish legions.

Constantine, who had seized the Roman Empire, still chose to rule the country in cooperation with Christianity, which originally taught the middle and lower classes of people who were humiliated and oppressed to endure, etc., but he took out of context and emphasized the part of forbearing unilaterally, advocating that people should absolutely obey their own leadership and be able to endure. He promoted Christianity to pave the way for his arbitrary power. Constantine also relied heavily on the strict organizational structure of Christianity. With his support, Christian organizations had penetrated into various provinces and even towns, and he used this organization to issue his own policies, his enlightenment to the people, and various decrees to the grass-roots level, thus effectively governing the whole country.

\section{THE INFLUENCE ON THE EMPIRE FROM RELIGIONS.}

It can be seen that the religion was never absent from the time of Roman Empire. The development of the Christianity has been along with the history of Rome and 
plays a big role during the governance. We will mainly discuss the positive side below.

Primarily, the empire has gotten the legality of the royal power from the church, the representative of the Christianity. For instance, the pope was supposed to grant the crown for the king at the coronation as a routine [3]. To explore the reason of this rule, we'd better look back to the early development of the Christianity. The original assemble of the religion was related to the customs in Rome, and then more and more rich people took part in the activities and donated to hold the opportunity of speech, which has built the basis of the religion. With the spread of the doctrine, female nobility accepted it more and brought others in.And then the theoretical system of Christian doctrine has been gradually being perfected and richer, and the church has forged writings in order to emphasize the sacred, persuading people that the church deserves more glory and better treatment. As we all know, the influence of the mental guidance is huge and that's what the religion has on the followers. Therefore, the church led a large crowd of Christians with strong belief. The empire just needs such followers with loyalty, and the ruling class take actions to establish a stable relationship with the church by supporting the religion[4], which shows the acceptation from the religion in Christians' minds.

Secondly, the religion contributes to the governance of the empire and plays a role in deciding the ruler. [5]From the history, it indicates that the relationship between them is not unidirectional. According to the development of the Christianity, we can see that people from the lowest classes and then the aristocracy accepted the religious faith in succession, from which they could get support because of different living experience and psychological demand. And that's why the religion has humorous power in society and much influence far and wide. On the other hand, the political power from the empire could provide the Christianity with protection and assistance to help them grow stronger. More importantly, it is the will of the people that matters over the issue of the kingship legality even though the democratic system had not shown up yet at that time. As the religion has been gaining strength, the ruling class of the Roman Empire could acquire more support of the public and was able to be against the other opponent in politics by cooperating with the church.For example, whenever a political conflict happened, the church showed up and stood for one of the parties. Then the noble followers may keep up with the side which the church has chosen because of their firm faith, which may result in the failure of the other side.

What's more, the organization of the church was conducive to imperial unity. For the Roman Empire possessed a vast territory, it is difficult to control every city, and the local lords may hold more power than expected, which means the central power would be cut down [6]. It may occurred that the king's actual control over the territory and resources reduced, the local lords wouldn't obey the king's requirement and ran their own affairs and so on. However the church could unite the empire via ideological leading, showing more contributing than the lords with independent wealth.Only when people are of one mind and loyal to the same belief, will they make efforts to protect the unity. In conclusion, the church did help to strengthen the cohesion of a nation.

\section{THE ROLE OF RELIGION IN MAINTAINING THE RULE OF ANCIENT KINGSHIP}

From the case of the connection between Rome and the Christianity discussed above, it can be seen that the religion did carry a lot of weight in an empire's history and have positive effects to some extent, which has not occurred only in Rome. If we observe others, we can also find that different religions have participated in their course of history. And we can say that people have chosen the way of god's giving divine right to promote the social process, at the same time, the formation of the system under this idea also has different influences on human society itself. In summary, the effect of the religion on the empire's governing are divided into three aspects in detail below.

\subsection{For the legitimacy of kings' ruling}

The god of the religion was mentioned of giving legitimacy of the royal power to kings of the empires in the theory of emperor's power from god, which is on the footing of the statement that we have to admit the religion is one of the most momentous methods of influencing people's minds. The trend of the bond between emperors and religions depends on people's spiritual world that joins them together:the religions have an effect on people's thought, and their behavior and choices are the support and foundation of the royal power. In other words, they need citizens to trust the existence of gods and have a strong belief about their words, and then strengthen ties and bonds between the kings and gods, in order to make the secular authority legal to be admitted by a holy and supreme level[7].

It is instinctive that people always pursue beatific and steady life on the basis of an orderly society, yet there were political upheavals frequently all over the world in ancient history, which has threatened people's minds unavoidably. And Augustine, the well-known thinker on behalf of Christian religion, has depicted the City of God and the City of Man, reflecting the situation. He said, only the chosen of God are entitled to be inhabitants of the city of God, and the City of Man can be inhabited only by the rejected of God, but both of them are controlled by God. The throne of the city on earth is created by God for his own purposes, and who becomes king is determined by 
god's will. Augustine's argument laid the theoretical foundation of the divine right of Kings in medieval Western Europe. And the royal power was established in this way, for the theory not only explained the social chaos at that time, but also gave the helpless people a kind of beautiful yearning[8].

\subsection{For the effect on people's minds}

As we can see from historical records, it is the teachings of religion that strengthen the control of the public mind and then let's take China as an example. The traditional Chinese religions has shown a kind of selfexistence of "seeking more blessings", which has been serving the dominant value of society, and its belief practice itself has become quite utilitarian in the folk. [9]After the Tang Dynasty, there was an obvious trend in Chinese culture, which was the confluence of Confucianism, Buddhism and Taoism. After the conflation, Chinese culture takes the Confucian traditional values of human relations and ideal of life as the core, combines the thinking and practice mode of Buddhism focusing on spiritual cultivation. The main content focused on people and the king of the country was obliged to build better living condition for them on behalf of the god.This development shows a more understanding way to convince Chinese people of obeying the ruling class when they have been gradually thinking in such system requiring a strong connection between their own behavior and life and the ordering of the society [10].

\subsection{For contributing to society's unity}

What's more, the religion can also help shape the social community as a whole and strengthen the unity in a nation. For the ruling regions with vast territory and numerous nationalities, such as Rome and China,the division and alienation within the empire are serious.It is possible when the authority is divided into pieces, the central power may be cut down led to disunity. Then the existence of religion would form a common belief gradually among the nation, which could weaken the rebellion of the local force to some extent, for they could not set themselves against their belief and the holy god.The religion help the secular power set up a more convincing character to trust at a level higher than anything in human's world,and when people devote themselves to the belief, the unity of the country would be strengthened.

\section{CONCLUSION}

In the first part of the essay, we mainly discussed the origin and development of Christianity in Roman Empire. The formation of Roman Empire is first discussed at the beginning, followed by the answers of several key questions: How Christianity gradually became the official religion in Roman Empire, How Constantine used
Christianity to consolidate his control of Roman Empire and so on. There are mainly three aspects being discussed in the second part: one is that the legitimacy of royal power is related to the gods in the Christianity religion; the other is that religion has a profound influence on the way of thinking of the people in that empire; the third is that religion can promote the unity of a country and strengthen cohesion between emperor and ordinary people.The rule of the Roman Empire was based on the conquest and assimilation of different nations and areas, and its roots were inherently unstable. In order to maintain the rule, the imperial governors set a series of political, economic, cultural and military strategies to adjust to the various social contradictions within its jurisdiction. objectively speaking, the strategy which is used to rule the empire implemented by the Roman Empire created favorable conditions for the spread and development of early Christianity.In the process of officialization of Christianity in Roman Empire, the church has been greatly developed, and it has also adjusted itself. The pattern of the relationship between state and church formed during this period had a profound impact on the future Western civilization. It is believed that in the development of the relationship between early Christianity and the Roman Empire, the third force, which is the non-Christian people, played an important role. In the interactive relationship between early Christianity, the imperial government and the nonChristian people, the growth of Christianity has its inherent inevitability.

Compared to other essays, our essay has a number of advantages. For example, we discuss role of Christianity from various perspectives, from the origin of Christianity in Roman empire to the ways that Constantine promoted Christianity and used it for himself. Also, we mentioned that Christianity, as a religion, has the power of controlling people's mind and thoughts, providing foundation for the future prosperity of the empire. Nonetheless, there is still spare spaces left for further exploration of influences of Christianity on Roman Empire from a deeper perspective. For example, we do not discuss the complete history of formation of Christianity in Roman Empire, which is essential for readers to understand and worth illustrating comprehensively. As a result, this is the goal that we will focus on and achieve in future researches.

\section{REFERENCES}

[1] Cyril Mango \& Roger Scott, The Chronicle of Theophanes Confessor: Byzantine and Near East History AD 284-813, Oxford: Clarendon Press, 1997, pp. 653, 647.

[2] L. Duchesne, Le Liber Pontificalis, Vol. I, Paris: Ernest Thorin, 1886, p. 453. 
[3] F. Kurze, Annales Regni Francorum, MGH, Scriptores rerum Germaniae 6, A. 814, Hannover: Hahn, 1895.

[4] Christian Scholl, Transcultural Approaches to the Concept of Imperial Rule in the Middle Ages, Frankfurt am Main: Peter Lang GmbH, 2017.

[5] Wang Yinhong, "Meaning imagination" and institutional expression of the "diversity" of the Holy Roman Empire ", Journal of East China University of political science and law, 2021 (2): 173-183.

[6] James Bryce, Holy Roman Empire, translated by Sun Bingying, Zhao Shiyu school, commercial press, 1998 .

[7] Wang Yinhong, "Secular Transformation and Political Expression of the Religious Conflict: Peace of Westphalia and the Order Construction in the Holy Empire”, History Monthly, 2021(7) :101-108.

[8] Li zenghong, "Seeing about the Thought of Divine Right of Kings in Ancient and Medieval Europe", Journal of Capital Normal University (Social Sciences Edition), 2004(5):27-33.

[9] Xu Xingyan, Comparison of Chinese and Western cultures, Beijing: Peking University Press, 2004.

[10] Tong Defu, "A comparison of Chinese and Western religious views", Journal of Central University for nationalities(Philosophy and Social Science Edition), 2005 (1): 41. 